NBER WORKING PAPER SERIES

\title{
LABOR MARKET INSTITUTIONS IN THE GILDED AGE OF AMERICAN ECONOMIC HISTORY
}

\author{
Suresh Naidu \\ Noam Yuchtman \\ Working Paper 22117 \\ http://www.nber.org/papers/w22117
NATIONAL BUREAU OF ECONOMIC RESEARCH
1050 Massachusetts Avenue
Cambridge, MA 02138
March 2016

This article is forthcoming as a chapter in The Oxford Handbook of American Economic History, edited by Lou Cain, Price Fishback and Paul Rhode. We thank Joe Ferrie, Claudia Goldin, Bob Margo, and Josh Rosenbloom for assistance with data and Lou Cain, Barry Eidlin, Price Fishback, Alex Gourevitch, and Sanjukta Paul for their comments. Carlos Avenancio provided excellent research assistance. The views expressed herein are those of the authors and do not necessarily reflect the views of the National Bureau of Economic Research.

NBER working papers are circulated for discussion and comment purposes. They have not been peer-reviewed or been subject to the review by the NBER Board of Directors that accompanies official NBER publications.

(C) 2016 by Suresh Naidu and Noam Yuchtman. All rights reserved. Short sections of text, not to exceed two paragraphs, may be quoted without explicit permission provided that full credit, including (๑) notice, is given to the source. 
Labor Market Institutions in the Gilded Age of American Economic History

Suresh Naidu and Noam Yuchtman

NBER Working Paper No. 22117

March 2016

JEL No. N3,O10,P16

\begin{abstract}
$\underline{\text { ABSTRACT }}$
Although 19th century American labor markets were unencumbered by regulatory legislation, labor market institutions played an active role determining labor market outcomes and the distribution of income. We provide evidence of firm-specific rents in 19th century labor markets: employees in firms experiencing positive output price shocks earned significant wage premia, relative to very similar workers. Employees and employers bargained over rents in the labor contract, with workers striking to raise wages. We present data on strikes' frequency in the 19th century, and suggestive correlations between strikes and wages. The U.S. government supported employers in limiting strikes' efficacy. Strike-breaking actions included intervention by police and militia; employers often relied on less drastic, but still effective, judicial labor injunctions suppressing strikes. We document the rise of these injunctions, pointing to the important role played by the judicial branch in structuring (Northern) American labor market institutions prior to the rise of legislative regulation.
\end{abstract}

\author{
Suresh Naidu \\ Columbia University \\ 420 West 118th Street \\ New York, NY 10027 \\ and NBER \\ sn2430@columbia.edu \\ Noam Yuchtman \\ Haas School of Business \\ University of California, Berkeley \\ Berkeley, CA 94720 \\ and NBER \\ yuchtman@haas.berkeley.edu
}




\section{Introduction}

The 19th century was an era of historically high and increasing economic inequality in the United States, and an important dimension of this inequality was between capital and labor. In Figure 1, one can see that the wealth to income ratio was high by historical standards in the late 19th century until World War I; the concentration of wealth was also increasing, with the top one percent of households' share of wealth growing from around $20 \%$ in the middle of the 19th century to over $40 \%$ in the early 20 th century.

Figure 1: Economic Inequality and Labor Market Conflict in the 19th and 20th Centuries

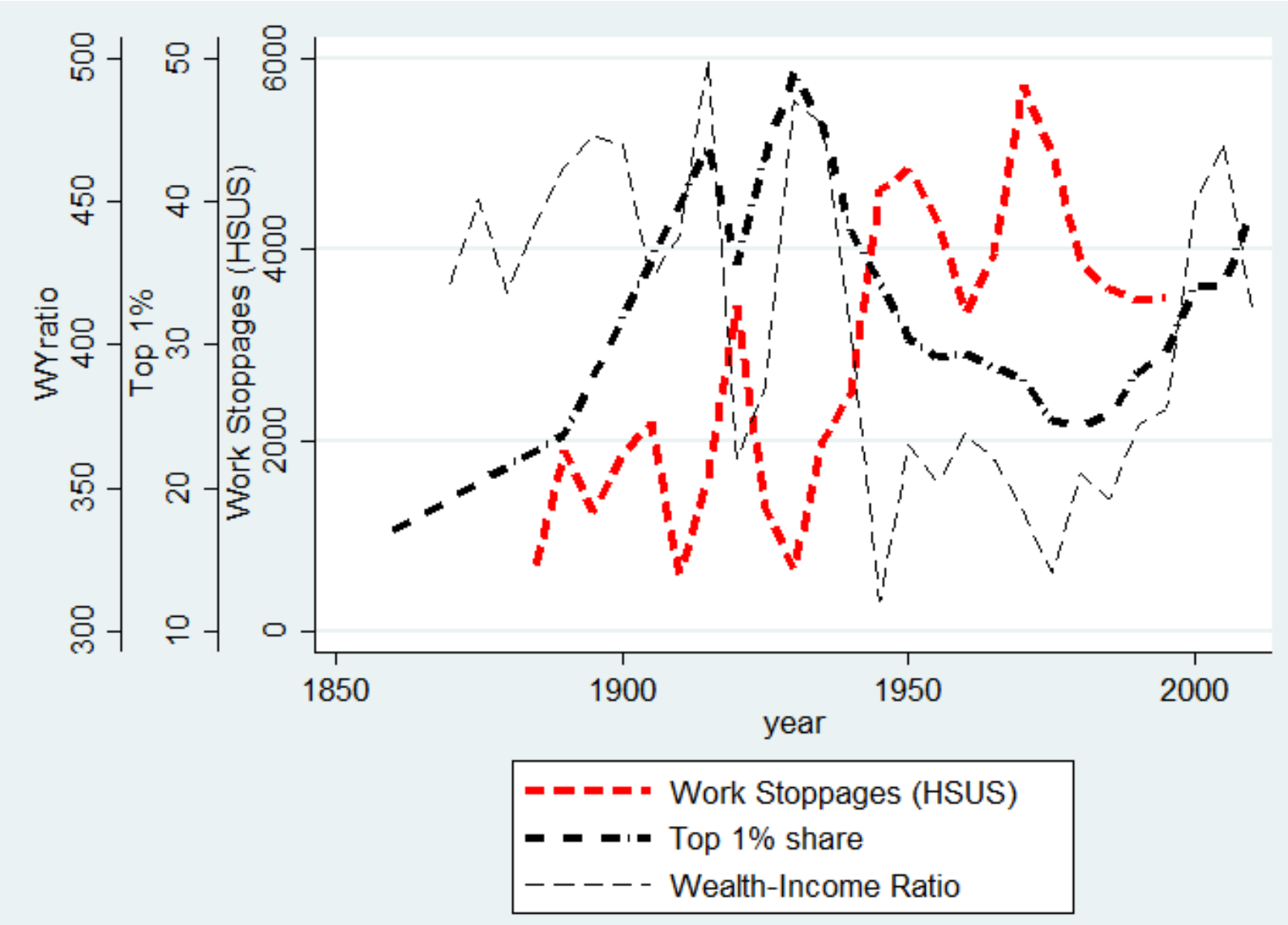

Figure shows the wealth to income ratio in the United States (from Piketty and Zucman, 2014 ); the share of wealth held by the top $1 \%$ of households (from Roine and Waldenstrom, 2015, and Saez and Zucman, 2016); and, the number of work stoppages per year (series Ba4954 from the Historical Statistics of the United States, 2006).

Did labor market institutions contribute to late 19th and early 20th century inequality? On the one hand, institutions were a central concern of early-20th century economists such as John R. Commons (1918) and of a large literature in the "new" labor history, examining the working class and the causes of Gilded Age labor conflict (e.g., Montgomery, 1987, and Brody, 1960). On 
the other hand, economic historians such as Fishback (1998) and Goldin (2000) have argued that markets played a more important role than the institutionalists suggested. Thus, one might believe that inequality was primarily a product of market outcomes. Indeed, the late 19th century Northern United States is sometimes viewed as an archetypal laissez-faire economy: markets, and particularly the labor market, were in fact largely unregulated institutional spaces. Especially in the cities, the free exchange of labor appears to have been close to a textbook labor market.

An economist casually observing late 19th century American labor markets might view the absence of regulation as an indication that a perfectly competitive labor market was at work. However, the absence of labor market regulation does not imply the absence of market imperfections or frictions. Nor does it imply that labor market institutions were irrelevant to the determination of wages and the distribution of income. Interestingly, in Figure 1, one can see a negative association between work stoppages - strikes, which reflect workers' attempts to increase their share of any rents in the labor market - and economic inequality in the late 19th and early 20th centuries.

In this chapter, we argue that labor market institutions and labor conflict indeed played an important role in shaping economic outcomes in the late 19th and early 20th centuries, but we take a somewhat different approach from the institutional economists and labor historians. Our perspective is influenced by modern research in labor economics, which highlights the importance of frictions in the labor market and bargaining over rents between workers and employers, as well as by political economy and law and economics research on strikes, conflict, and the importance of the judiciary. We present evidence that there existed frictions and rents in the 19th century (Northern) American labor market; moreover, conflict over the distribution of rents in the labor market - and the institutions that resolved them-played an active role in determining labor market outcomes.

We begin by presenting new evidence suggestive of rents in the labor market: when urban, industrial firms experienced (plausibly exogenous) positive output price shocks, their employees earned wage premia, relative to other employees with similar skills in the very same labor market. The existence of wage rents that were not competed away contributes new evidence to a rich, but mixed, historical literature on frictions in the U.S. labor market in the 19 th century. ${ }^{1}$

Fishback (1998) discusses a set of institutions that arose in response to 19th century labor market frictions, arguing that they reduced transaction costs. In this paper we complement Fishback's discussion of labor market institutions in the 19th century, focusing on institutions meant not to reduce transaction costs, but to determine the distribution of rents that were bargained over - sometimes battled over-by employers and employees. We focus on labor strikes, and the institutions - the police, militias, and especially the courts - that employers used to combat them. Worker strikes, and employers' attempts to squash strikes with legal injunctions, we argue, represented institutional determinants of the distribution of rents, rather than simply institutions that reduced transaction costs.

We present evidence on strikes in the late 19th century: we show the rising frequency of strikes

\footnotetext{
${ }^{1}$ Our focus is on the labor market institutions of the late 19th and early 20th centuries; see Goldin (2000) for a discussion of labor market institutions in the 20th century, including the important changes of the New Deal era.
} 
across time (using data from the Historical Statistics of the United States, 2006); the increase in the number of labor-related events involving violence (from Turchin, 2012); and the number of deaths arising from labor conflict (again, from Turchin, 2012). Next, we examine the impact of strikes on employee wages in the late 19th century; we find that controlling for a variety of firm characteristics, strikes were correlated with higher wages. ${ }^{2}$ We also present evidence on the determinants of strikes' outcomes, finding that a crucial determinant of strikes' outcomes was the ability of employers to hire replacement workers. That is, the distribution of labor market rents-going to incumbent workers, or going to employers and to replacement workers-was at the crux of labor market conflict in the late 19 th century.

Next, we present evidence on the legal institutions - in particular judicial labor injunctionsthat supported employers' efforts to suppress worker strikes in the late 19th and early 20th centuries. Labor injunctions were legal requests made by employers to judges to end a labor strike and force employees to return to work (a substitute for hiring replacement workers that might be especially desirable when the latter option was costly). Injunctions also broke up picketing or other activities that prevented replacement workers from continuing work. We used the legal databases LexisNexis and Westlaw to identify all reported cases involving a legal injunction used as a remedy in a labor dispute between 1875 and 1930. One can see a sharp rise in the use of injunctions in the late 19th and early 20th centuries; we build on Currie and Ferrie (2000), who examine the effects of the legal "rules of the game" on labor market outcomes, and follow Orren (1991) in pointing to the crucial role played by the judicial branch in establishing the rules of the game in the 19th century labor market. ${ }^{3}$

Our analysis suggests that economic historians ought to devote more attention to the de facto labor market institutions that determine the distribution of rents within the labor relationship, as well as to the courts that often set the rules of the bargaining game. We also believe that our study of labor market institutions in the Gilded Age has lessons beyond the historical setting studied, especially in light of contemporary scholarship (e.g., Piketty, 2014) documenting recent increases in income and wealth inequality - the possible rise of a second Gilded Age (refer again to Figure 1). A first lesson of history and recent scholarship is that high levels of inequality can be associated with wasteful (sometimes violent) social conflict (Esteban and Ray, 2011), or wasteful expenditures to deter and suppress this conflict (Bowles and Jayadev, 2006). Second, while contemporary policy proposals aimed at reducing inequality often focus on income taxation and redistribution, our examination of the 19th century labor market institutions suggests the importance of policies affecting the distribution of rents within the labor contract. Increasing workers' bargaining power,

\footnotetext{
${ }^{2}$ The occurrence of strikes could also have long-run effects on labor market outcomes. Hanes (1993) shows that industries in which firms experienced more strikes in the early 1880s were less likely to cut wages during the downturn in 1893. He argues that the fear of strikes, and the resulting increase in workers' bargaining power, generated wage rigidity even in the absence of legally binding contracts.

${ }^{3}$ Currie and Ferrie (2000) find that changes in the laws governing labor conflict in the late 19th century did not typically have the effects expected by their proponents. In particular, they find no significant effect of labor injunctions on strike outcomes. However, their measure of injunction activity is simply an indicator that an injunction had previously been issued and sustained by a federal or state court in a labor dispute in a particular state. This sort of state $\times$ year level variation might be too coarse to capture any effect of injunctions.
} 
changing the distribution of rents between high- and low-skill workers, and between workers and firm owners could play an important role in reducing contemporary inequality.

The remainder of the chapter is organized as follows: in Section 2 we present evidence on frictions and rents in the 19th century American labor market; in Section 3, we document patterns of strikes and labor conflict in the 19th century and provide evidence on the determinants of the outcomes of labor conflict; in Section 4 we describe the role played by the judicial branch in limiting strikes; finally, in Section 5, we conclude with a discussion of promising directions for future research.

\section{Frictions and Rents in 19th Century American Labor Markets}

Economic historians have found that supply and demand were important drivers of the level and distribution of wages in the late 19th and early 20th centuries. Fishback (1998, p. 722), reviewing the literature on the 19th century American labor market, writes:

Turn-of-the-century America offers an unusual empirical opportunity to expand our understanding of the operation of largely unregulated labor markets. The American experience between 1890 and 1930 illustrates the roles of exit and voice in determining worker welfare in the absence of unemployment insurance, social security, wage and hour regulations, the National Labor Relations Board, anti-discrimination laws, and many other modern regulatory influences.

Fishback (1998, p. 723) continues:

Turnover rates were higher in the early 1900s than in the modern era and there were strong signs of labor market integration between most regions of the United States. The South, which some consider isolated, offered numerous opportunities for workers to raise their earnings near levels in the North through migration within the region. The combination of competition among employers and the use by workers of both exit and collective action served to limit the extent to which employers could earn monopsonistic rents from their workers in the long run.

Yet, labor historians and economic historians, including Fishback, also find evidence of significant frictions, rents to be bargained and fought over, and the existence of institutions that fundamentally shaped labor market outcomes. There are disagreements, however, about how much these factors interfered with the operations of supply and demand in labor markets.

From one perspective, the primary determinants of employment and wage patterns are supply and demand, and these were surely important drivers of the level and distribution of wages. Both labor supply and demand certainly changed in important ways in the late 19th century. On the supply side, of paramount importance were the massive inflows of immigrants, which increased the supply of labor in the late 19th century (see, e.g., Abramitzky et al., 2012). Expanded schoolingthe establishment of common schools, then the expansion of secondary schooling (Goldin and Katz, 2008) — was undoubtedly important, too, in shaping the distribution of earnings. 
On the labor demand side, the 19th century U.S. saw the rise of the large corporation (e.g., Chandler, 1977) and rapid technical change (e.g., Atack, Bateman, and Margo, 2008). Goldin and Katz (1998) and Katz and Margo (2014) explore the effects of factory production and the introduction of new technology on the demand for workers with differing skill levels. They find increased demand for skilled labor coming from complementarities with new technologies, such as electrification in the early 20th century, as well as a "hollowing out" of the occupational distribution, with 19th century manufacturing crowding out traditional artisans, and substituting the labor of low-skill workers and high-skill, white collar workers.

Increased productivity was (at least partially) reflected in workers' wages in the late 19th and early 20th centuries, with unskilled workers' real wages rising slowly, but steadily, from 1860-1918 (see Figure 2). Were the higher wages earned commensurate with changes in workers' marginal products? The mapping from worker productivity to wages might not have been so simple: in addition to supply and demand, labor market outcomes may have been shaped by frictions, the distribution of rents that were bargained and fought over, and the functioning of labor market institutions.

Indeed, economic historians have collected a wide range of evidence on the imperfections in 19th century labor markets despite the lack of regulatory interference. One obvious labor market friction was simply imperfect worker mobility. Rosenbloom (1996), using census earnings data, suggests that "although labor market integration was proceeding on a regional level, this process did not extend to the national level." While Rosenbloom focused on geographic wage dispersion, he also points to other frictions: recruitment costs meant that employer search depended on recruiting through social networks; wages, he notes, did not adjust to reflect variation in local amenities, such as infant mortality.

Recent work reveals substantial firm-specific wage premia even in contemporary labor markets (Card et al., 2016). One source of these premia is employee investment in firm-specific human capital, which produces rents within the employment contract to be bargained over between employees and (incumbent) employers (see, e.g., Jäger, 2016). Sundstrom (1988) presents evidence that firms in the 19th century U.S. relied on internal promotion to fill skilled positions, which suggests that workers acquired valuable firm-specific skills on the job. Long tenures for employees also point to an important role for firm-specific human capital (see Carter and Savoca, 1990, James, 1994, and Sundstrom, 1988; see also Jacoby and Sharma, 1992, for an alternative perspective).

Another literature has looked explicitly at monopsony in the 19th century labor market. Fishback (1992) and Boal (1995) examine monopsony in 19th century coal mining, and find some evidence of monopsony power, though they emphasize relatively low rates of "exploitation" (i.e., gaps between wages and marginal product) and high rates of worker mobility across employers. ${ }^{4}$

\footnotetext{
${ }^{4}$ Fishback (1992) writes, "The high degree of mobility of workers offers evidence that workers exercised their opportunities to exit despite the presence of migration and information costs. ... [Worker] turnover was widely recognized in the historical studies but the view of monopsony and exploitation still prevailed in the historical analysis of the industry. A series of studies offers a quite different picture of the coal industry, one in which the miners' mobility and exit play a substantially more powerful role than previously believed."
} 
Figure 2: Real and Nominal Unskilled Workers' Wages, 1860-1918

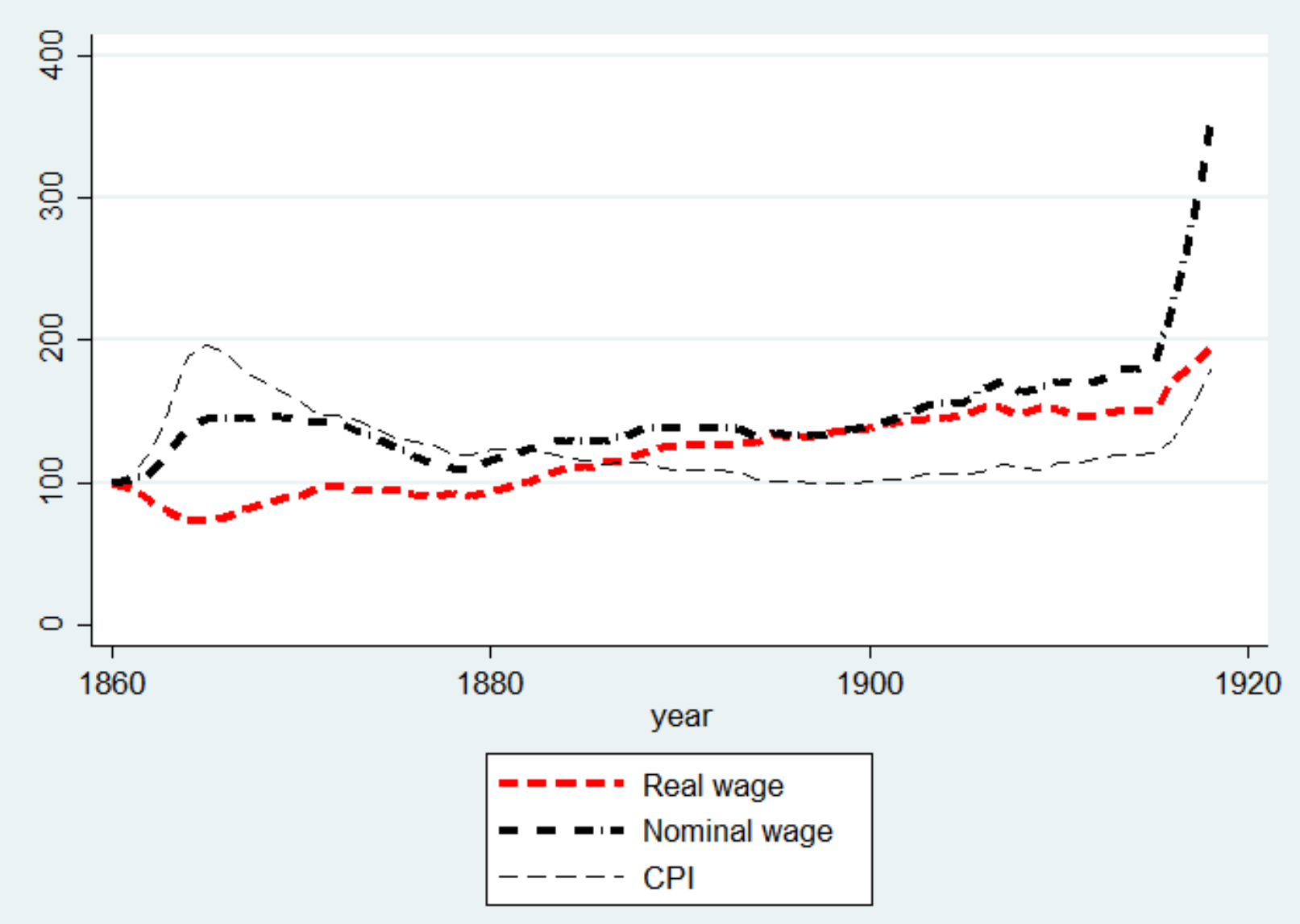

Figure shows the evolution of unskilled workers' nominal wage, price level, and unskilled workers' real wage indices $(1860=100)$, from 1860 to 1918 . All data come from the Historical Statistics of the United States, 2006: the nominal wage index is series Ba4218 and the price index is series Cc2 (the real wage is their ratio).

Zevin (1975) and Vedder, Gallaway, and Klingaman (1978) present evidence suggesting some degree of employer monopsony power among urban textile mills in the 19th century. Our reading of the literature is that there is no doubt that 19th century labor markets were affected by search frictions, and there existed some rents in the employment relationship - yet the extent of the imperfection remains very much the subject of debate. ${ }^{5}$

We take a different approach to studying frictions in 19th century labor markets, using the 1850-1880 national samples from the 19th century Census of Manufacturing (collected by Jeremy Atack, Fred Bateman, and Thomas Weiss) to test for firm-specific wage premia. ${ }^{6}$ To do so, we

\footnotetext{
${ }^{5}$ Ziebarth (2013) presents more general evidence of misallocation in the 19th century U.S., despite the relatively laissez faire institutions. Indeed, he finds that the TFP loss due to distortion is quantitatively similar to that of China and India today.

${ }^{6}$ These samples were downloaded from the website of Jeremy Atack; see https://my . vanderbilt.edu/jeremyatack/data-downloads/, last accessed May 2015.
} 
examine the relationship between firms' value added per worker and employee wages. While it would not be surprising if the value added of firms were correlated with wages across markets, in a perfectly competitive market there should be little variation in wages across firms in the same industry, within the same labor market, at a single point in time, particularly once skill and worker characteristics are accounted for. ${ }^{7}$

Table 1: Summary Statistics: Census of Manufacturing

\begin{tabular}{lccc}
\hline \hline \multicolumn{1}{c}{ Variable } & Mean & Std. Dev. & $\mathrm{N}$ \\
\hline Labor (Raw) & 11.322 & 41.853 & 8305 \\
Monthly Average Wage (1\% Winsorized) & 26.777 & 16.306 & 8305 \\
Capital & 8312.277 & 36168.466 & 8305 \\
Value Added Per Unit Labor & 755.068 & 1254.086 & 8305 \\
Rural & 0.788 & 0.409 & 8305 \\
Output 1 Price & 50.45 & 275.307 & 3570 \\
Fraction Men & 0.954 & 0.146 & 8305 \\
Skill Premium & 1.91 & 0.755 & 2711 \\
\hline \hline
\end{tabular}

Data come from the 1850-1880 national samples of the Census of Manufacturing collected by Jeremy Atack, Fred Bateman, and Thomas Weiss.

A series of papers by Jeremy Atack, Fred Bateman, and Robert Margo have used these data to document patterns in the manufacturing sector in the late 19 th century. ${ }^{8}$ The work closest to what we do here is Atack, Bateman, and Margo (2004), in which the authors look at patterns of wage dispersion between 1850 and 1880. They find that, ceteris paribus, larger firms had lower wages, as firms adopting modern production methods had a lower demand for skill. In addition they find that wage dispersion was increasing over this period, as the increasingly important larger firms employed lower wage workers. Katz and Margo (2014) argue that rather than strict "de-skilling", the 19th century saw a "hollowing out" of the labor market, as middle-skill jobs disappeared.

We provide summary statistics from the Manufacturing Census data in Table 1, showing the size of a firm's workforce; average monthly wages, constructed following Atack, Bateman, and Margo (2004); value added per worker; output prices; and, information on the gender and skill composition of a firm's workforce. We begin our analysis simply by documenting correlations in the raw data between firms' value added per worker and firms' average wages. In the left-hand panel of Figure 3 we show a scatterplot of wages against firm value added per worker, along with the best-fit linear relationship. One can see that, unconditionally, higher value added firms paid higher wages.

\footnotetext{
${ }^{7}$ Our examination of wage differences across industries and across firms is closely related to work on labor market rents in the 20th century. See Katz and Summers (1989) for a cross-industry analysis and Davis and Haltiwanger (1991) for a cross-plant analysis.

${ }^{8}$ Atack, Bateman, and Margo (2002) document wage differences between manufacturing plants that operated year-round and those operating for only part of the year. Atack, Bateman, and Margo (2003) estimate the elasticity of output with respect to hours worked, finding a positive coefficient significantly smaller than 1. In Atack, Bateman, Margo (2008), the authors document that steam power was increasingly used over the 19th century, was more likely to be used by larger establishments, and had a positive effect on labor productivity.
} 
Figure 3: The Relationship Between Firms' Wages and Value Added
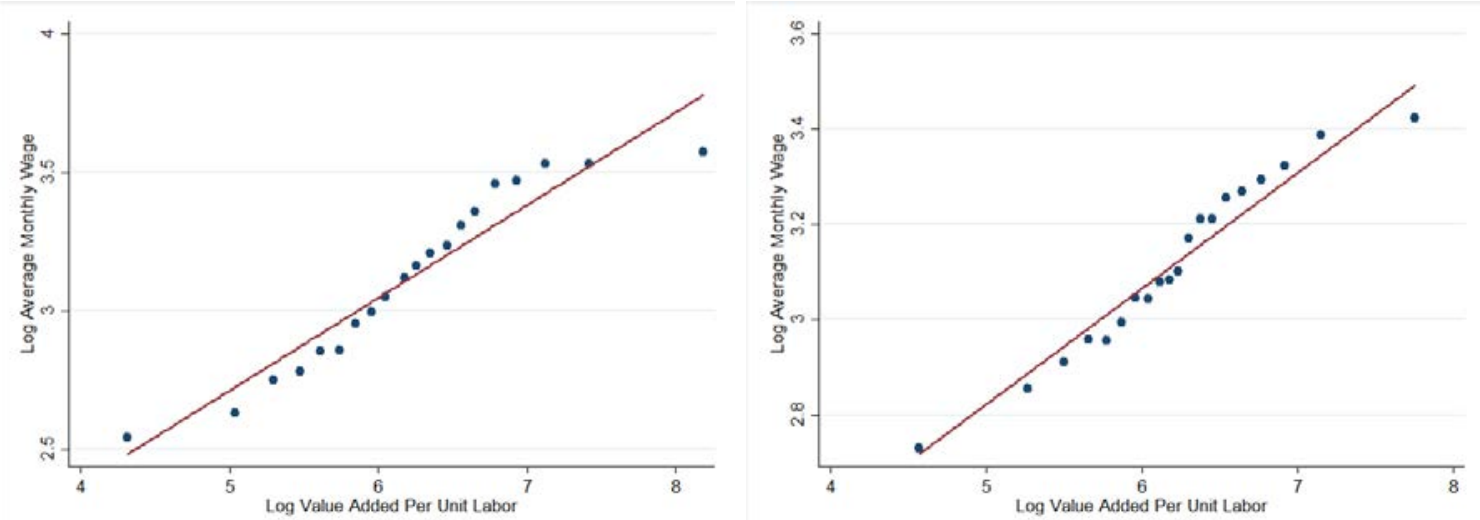

Figure shows binned scatterplots of firms' log average wages against log value added per worker. Left-hand panel shows unconditional values. Right-hand panel absorbs city $\times$ industry $\times$ year fixed effects and plots residuals. Firm-level data on wages and value added per worker are from the national sample of the Census of Manufacturing 1850-1880 collected by Jeremy Atack, Fred Bateman, and Thomas Weiss.

Of course, higher value added firms may differ from lower value added firms in a variety of ways, and wages may differ across these firms for a variety of reasons other than labor market imperfections. To more directly examine differences in wages across firms that ought to be competing in the same labor market, we next examine the relationship between value added and wages conditional on city $\times$ industry $\times$ year. In the right-hand panel of Figure 3 we show a scatterplot of wage residuals (conditioning out the city $\times$ industry $\times$ year fixed effects) against value added per worker residuals. One can still see a strong positive relationship between firm value added and wages - even looking within the same city, within the same industry, within the same year.

We next examine the robustness of the relationship between wages and value added, estimating a series of regressions. We begin by regressing log average wages on log value added per worker, conditional on city $\times$ year fixed effects. The motivation behind this specification is that cities are natural labor markets, and systematic firm-level variation in wages conditional on these fixed effects provides a first indication that there is not a single market wage facing all firms. We thus estimate the following model:

$$
\log \left(w_{i j c t}\right)=\beta \log \left(\frac{V_{i j c t}}{L_{i j c t}}\right)+X_{i} \gamma+\delta_{j}+\delta_{c t}+\epsilon_{i j c t}
$$

where $w_{i j c t}$ is the $\log$ monthly average wage paid by firm $i$, in industry $j$, in city $c$, in year $t$; $V_{i j c t}$ is the value added of the firm, and is the difference between sales revenue of firm $i$ and $C_{i j c t}$, the firm's non-labor input costs; $L_{i j c t}$ is a firm's raw labor input ${ }^{9} ; X_{i}$ is a set of firm level characteristics,

\footnotetext{
${ }^{9}$ Atack, Bateman, and Margo (2003) adjust the labor input to reflect workers' composition as follows: adjusted labor $=($ no. of men $)+0.6^{*}($ no. of women $)+0.5^{*}$ (no. of children $)$. Using labor inputs adjusted this way does not affect our results.
} 
generally fraction male and the log of the value of the capital stock; $\delta_{j}$ are a set of industry fixed effects; $\delta_{c t}$ are a set of city $\times$ year fixed effects; and $\epsilon_{i j c t}$ is a firm-specific error term.

In Table 2 , column 1 , one can see that within a city $\times$ year cell, higher value added firms pay higher wages than lower value added firms: we estimate that a $10 \%$ increase in a firm's value added translates into a $2.3 \%$ increase in monthly wages. In column 2 , we estimate a model nearly identical to equation (1), but adding controls for log capital and the fraction of a firm's workforce who are adult men, as well as industry fixed effects. In column 3, we estimate the specification from Table 2, column 1, but now include a full set of city $\times$ industry $\times$ year fixed effects to account for cross-industry (within city $\times$ year) variation in wages (note that all specifications in Table 2 are restricted to city $\times$ industry $\times$ year cells with at least 4 firms). Column 4 shows the same specification as column 3, but restricted to cities with at least 10 firms, i.e., "urban" labor markets. In Table 2, column 5 , we add to the specification with city $\times$ industry $\times$ year fixed effects controls for log capital and for the fraction of a firm's workforce who are adult men. Next, in Table 2, column 6, we examine whether wage differences across firms simply reflect different skill premiums paid in high value added firms. We do so by controlling for the ratio of a firm's skilled wages to its unskilled wages. Our results across specifications are qualitatively similar to those in column 1: firms in the same city, in the same industry, paid their workers different wages associated with the firms' value-added.

A concern with our analysis thus far is that unobserved firm characteristics could be behind both greater value added and higher wages. We next try to isolate the relationship between wages and plausibly exogenous variation in firm value added, using the price of a firm's primary output as an instrument for its value added. The logic behind this instrumental variable analysis is that each firm takes its output price as given, and movements in the output price can generate variation in a firm's value added. ${ }^{10}$ Note that output price data are not available for 1880 , so our analysis is limited to the 1850-1870 censuses. In Table 2, column 7, we present second stage results from a two-stage least squares estimate in which the price of the primary output product of firm $i$ in year $t$ is an instrument for the value added of firm $i$ in year $t .{ }^{11}$ One can see that the coefficient on the firm's value added in the second stage is smaller than what was found in the OLS regressions; however, variation in value added driven by firm output prices (plausibly exogenous with respect to a single firm) remains positively associated with firm wages. ${ }^{12}$

In sum, these regressions show that even within labor markets, defined either as cities or city $\times$ industry cells, firm value added is significantly correlated with firm wages. This suggests the existence of firm-specific rents that are not competed away. Our data do not allow us to iden-

\footnotetext{
${ }^{10}$ Indeed, the instrument is quite strong: as reported in Table 2, column 7, the F-statistic from the first stage is nearly 45.

${ }^{11}$ We do not include city $\times$ industry $\times$ year fixed effects as this would absorb nearly all of the variation in value added associated with a firm's output price.

${ }^{12}$ In addition, the instrumented value-added positively predicts employment, with a significant coefficient of 0.41 , further suggesting that firms faced upward-sloping labor supply curves. Indeed, the implied labor supply elasticity facing the firm is 2.8, suggesting substantial monopsony power, with workers paid roughly $65 \%$ of their marginal product.
} 
Table 2: Correlations Between Log Wages and Log Value Added

\begin{tabular}{|c|c|c|c|c|c|c|c|}
\hline \multicolumn{8}{|c|}{ Dependent Variable: Log Average Wage } \\
\hline & $(1)$ & $(2)$ & $(3)$ & $(4)$ & $(5)$ & $(6)$ & $(7)$ \\
\hline \multirow[t]{2}{*}{ Log(Value Added/Labor) } & 0.234 & 0.204 & 0.243 & 0.327 & 0.210 & 0.289 & 0.147 \\
\hline & $(0.015)$ & $(0.014)$ & $(0.019)$ & $(0.041)$ & $(0.016)$ & $(0.021)$ & $(0.074)$ \\
\hline \multirow[t]{2}{*}{ Fraction Men } & & 0.589 & & & 0.582 & 0.360 & \\
\hline & & $(0.053)$ & & & $(0.056)$ & $(0.087)$ & \\
\hline \multirow[t]{2}{*}{ Log Capital } & & 0.051 & & & 0.049 & 0.068 & \\
\hline & & $(0.007)$ & & & $(0.007)$ & $(0.013)$ & \\
\hline \multirow[t]{2}{*}{ Skill Premium } & & & & & & -0.018 & \\
\hline & & & & & & $(0.018)$ & \\
\hline City X Year FE & Yes & Yes & No & No & No & No & Yes \\
\hline City X Industry X Year FE & No & No & Yes & Yes & Yes & No & No \\
\hline Industry FE & No & Yes & No & No & No & No & Yes \\
\hline City X Industry FE & No & No & No & No & No & Yes & No \\
\hline Sample & All & All & All & Urban & All & 1880 & $1850-1870$ \\
\hline Observations & 8305 & 8263 & 8305 & 1709 & 8305 & 2710 & 3506 \\
\hline $\mathrm{R} 2$ & 0.39 & 0.43 & 0.50 & 0.60 & 0.51 & 0.52 & 0.16 \\
\hline First Stage F & & & & & & & 44.53 \\
\hline
\end{tabular}

Outcome variable is the log average wage in all columns. Robust standard errors, clustered at the city $\times$ year level, in parentheses. Columns 1-6 show estimated coefficients from OLS regressions of a firm's log average wage on its value added per worker, plus controls indicated in the table. Column 7 shows estimated coefficients from the second stage of a 2SLS analysis in which a firm's value added per worker is instrumented for using the price of the firm's primary output. Sample restricted to industries in cities (including rural areas) with more than 3 firms, except for the "Urban" sample, which drops rural firms and those in cities with fewer than 10 firms. 
tify particular sources of rents; possibilities include firm-specific human capital, adverse selection, moral hazard, search frictions, norms of fairness, or intra-firm bargaining. Each of these sources, however, is consistent with the existence of rents to be bargained over between employers and employees.

Of course, there are other possible explanations for the observed correlation between wages and value added. For example, high wages at high value-added firms may be compensating differentials for a firm-specific disamenity. It is also possible that our results are driven by sorting of skilled workers into highly productive firms. These two alternative hypotheses would be addressed by our instrumental variables analysis if neither disamenities nor employee sorting varied with a firm's output prices. Controls for firm characteristics (such as the skill premium) should also help. However, we cannot entirely rule out the possibility that there exists some unobserved firm characteristic that is associated with both wage levels and value added.

Further evidence of rents in the 19th century labor market is the pervasiveness of costly rentseeking behavior. This was not limited to market interactions or lobbying for state policy, but also took the form of bloody conflicts between workers and employers (and replacement workers) as well as violent state repression. We next provide evidence of costly conflict over rents in the 19th century labor market.

\section{Labor Conflict}

The late 19th century saw the rise of the labor union as an economic, social, and political force. Still, the rapid increase in union membership in the late 19th century was built on a small base; relatively low union density meant that bargaining in the absence of formal unions was often necessary. ${ }^{13}$ The low level of formal union membership is one reason we emphasize (sometimes firm-specific) strikes over unions in collective bargaining; moreover, the existence of labor market frictions meant that worker organizations did not need to control an entire labor market in order to increase wages - withholding labor from the firm could impose severe costs on employers.

Importantly, strikers' leverage stemmed from their ability to prevent employers from using replacement workers. But strikers had little de jure power: the law did not prevent the hiring of replacements. While scarce skilled workers had high replacement costs, unskilled workers did not. Thus, for the threat of a strike to have bite, strikers often relied on the use of coercion (or at least the threat of coercion off the equilibrium path). Coercive action by workers included picketing, social pressure, political dealing, and sometimes violence to restrict the hiring of replacement labor. On the other side of the bargaining process, employers would do whatever they could to induce striking workers to return to their employment, or to force in replacement workers. While the

\footnotetext{
${ }^{13}$ While it is difficult to identify a causal union wage premium, the available evidence suggests that unions were able to secure wage increases for both unskilled and skilled workers. Paul Douglas, in his 1930 "Real Wages in United States 1890-1926", documented a substantial union premium; Eichengreen (1987), too, finds a union wage premium, using data from Iowa in 1884. Hatton et al. (1994) also find a union wage premium in 19th century Britain, which also saw rapid union growth.
} 


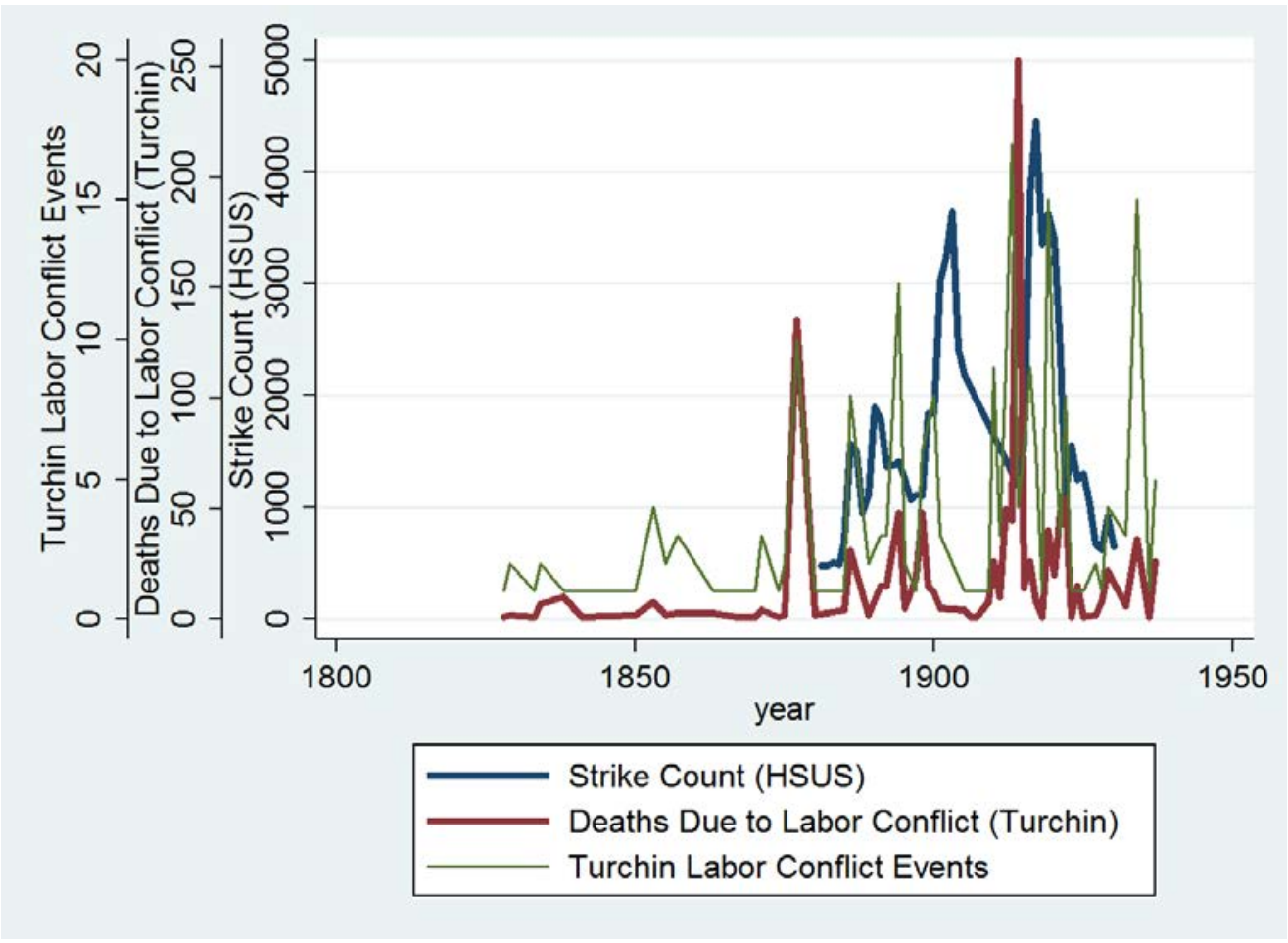

Figure 4: Figure shows time series data on the number of work stoppages in the U.S. (series Ba4954 from the Historical Statistics of the United States), the number of violent labor conflicts, and on the number of deaths occurring in labor conflicts (both from Turchin, 2012).

majority of labor conflicts were non-violent, bargaining over rents in the labor contract was at the root of increasing violent confrontation between workers and employers in the late 19th century.

While strikes were rare events, their increasing frequency and ferocity in the late 19th century led to widespread public concern, prompting several government investigations, and spurring the creation of the Bureau of Labor Statistics in 1884. In Figure 4, we present evidence of increasing labor conflict in three time series. First, we show the count of strikes, from the Historical Statistics of the United States. One can see a rise in the late 19th century, and large spikes in the early 20th century. We also show the number labor conflict events, and the number of deaths that occurred in labor conflicts, both from Turchin (2012). ${ }^{14}$ One can again see evidence of increased conflict in the second half of the 19th century, and peaks in the early 20 th century.

Were strikes successful in raising workers' wages? Strong causal claims are difficult to make due to the endogeneity of strikes: for example, workers may choose to strike disproportionately at firms that pay high wages. Still, it can be informative to examine the association between strikes and wages. We do so using data from the Weeks Report (1886). ${ }^{15}$ In Table 3, we first present summary

\footnotetext{
${ }^{14}$ Turchin (2012) constructs his dataset by combining data from Levy (1991) and Gilje (1996) with information collected from searches of online news databases.

${ }^{15}$ The Weeks Report was a study conducted by census agent Joseph Weeks, as part of the 1880 census. Note that it is based on a convenience sample and thus is not perfectly representative of firms. We downloaded the data from http://econterms.net/weeksreport/weeksdoc.htm, courtesy of Peter Meyers (last accessed November 17, 2015).
} 
Table 3: Summary Statistics: Firm Characteristics and Strike Activity in the Weeks Report

\begin{tabular}{lccc}
\hline \hline \multicolumn{1}{c}{ Variable } & Mean & Std. Dev. & N \\
\hline Log Daily Wage & 0.269 & 0.267 & 5059 \\
Experienced a Major Strike & -0.178 & 0.611 & 5059 \\
Hot Blast Technology & 0.045 & 0.206 & 5049 \\
Manager Reports High Labor Efficiency & -0.195 & 0.745 & 5059 \\
Fraction Female & 0.004 & 0.063 & 5059 \\
Fraction Child & 0.006 & 0.077 & 5059 \\
Fraction Black & 0.002 & 0.042 & 5059 \\
Fraction Asian & 0.005 & 0.065 & 5059 \\
\hline
\end{tabular}

Data come from the Weeks Report (1886). Sample restricted to post1865 years.

statistics for the Weeks Report data. The strike measure is either -1, if no strike was known to have occurred, 0 if it was unknown whether a strike had occurred, and 1 if it was known that a strike had occurred. We next regress firm wages on the experience of a strike.

In Table 4, column 1, one can see that there is, indeed, a positive and statistically significant relationship between strikes and wages. Because in some cases we do not know if there was a strike or not, in Table 4, column 2, we limit the analysis to those observations in which there was clearly a strike or no strike. One can see that examining only these strikes there remains a positive relationship between the experience of a strike and wages.

Of course, strikes may occur in particular industries, places, and times that would be associated with higher wages even in the absence of a strike. In Table 4, column 3, we thus add industry and year fixed effects, which capture many dimensions of a firm's environment that may be associated with both strikes and wages. One can see that the coefficient on the experience of a strike falls, but strikes remain associated with a higher wage. In Table 4, columns 4-5, we add to the specification in column 3 controls for the composition of a firm's workforce and state fixed effects. Strikes are positively associated with wages in both specifications.

Next, in Table 4, column 6, we control for workforce composition, as well as industry, state, and year fixed effects. We also include controls for firm characteristics that may be associated with both strikes and wage rates: the use of hot blast technology and manager reports that labor is used highly efficiently. Again we find a positive association between strikes and wages. Finally, we repeat the specification from Table 4, column 6, but limiting the analysis to observations in which there was clearly a strike or no strike. In Table 4 , column 7 , one can again see a positive association between strikes and wages.

We next explore the determinants of strike success, using data collected in Reports issued by the Commissioner of Labor. ${ }^{16}$ Here we build on much prior work on the empirical determinants of

\footnotetext{
${ }^{16}$ Currie and Ferrie (2000) collected and digitized the reports from the six states (MA, CT, IL, NY, NJ, PA) that accounted for $90 \%$ of strikes from 1880 to 1894. See also Card and Olson (1995) and Rosenbloom (1998). Note that
} 
Table 4: Daily Wages and the Experience of Strikes

\begin{tabular}{lccccccc}
\hline \hline \multicolumn{2}{l}{ Dependent Variable: Log Average Wage } & & & & & & \\
\hline \multicolumn{2}{c}{$(1)$} & $(2)$ & $(3)$ & $(4)$ & $(5)$ & $(6)$ & $(7)$ \\
\hline Experienced a Major & 0.039 & 0.048 & 0.036 & 0.035 & 0.025 & 0.021 & 0.029 \\
Strike & $(0.017)$ & $(0.016)$ & $(0.015)$ & $(0.015)$ & $(0.013)$ & $(0.012)$ & $(0.014)$ \\
Hot Blast Technology & & & & & & 0.212 & -0.440 \\
& & & & & & $(0.069)$ & $(0.053)$ \\
Manager Reports High & & & & & -0.025 & -0.015 \\
Labor Efficiency & No & No & No & Yes & No & Yes & Yes \\
Composition Controls & No & No & Yes & Yes & Yes & Yes & Yes \\
Year FE & No & No & Yes & Yes & Yes & Yes & Yes \\
Industry FE & No & No & No & No & Yes & Yes & Yes \\
State FE & No & Yes & No & No & No & No & Yes \\
Only Known & 5059 & 2052 & 5059 & 5059 & 5059 & 5049 & 2052 \\
\hline Observations & 0.01 & 0.03 & 0.27 & 0.30 & 0.48 & 0.55 & 0.57 \\
R2 & &
\end{tabular}

Regressions show the relationship between establishment characteristics - in particular, the experience of a strike - and wages. Standard errors clustered at the establishment level. "High Labor Efficiency" was reported by the establishment manager. Composition controls are fraction Black, female, Asian, and fraction child workers.

strike outcomes. ${ }^{17}$ For example, Card and Olson (1995), also using data from the Commissioner of Labor Reports, find:

Strikes ordered by a labor organization, strikes with fewer female workers, strikes initiated prior to the wave of unrest following the Haymarket incident in May 1886, strikes in the building trades and the shoe industry, and strikes involving a larger fraction of the firm's workforce were more likely to succeed. Interestingly, all of these factors raise the wage conditional on a successful strike. We interpret this finding as evidence that employers with greater potential rents had higher costs during a work stoppage.

We focus on the role of replacement workers in determining the outcomes of strikes. A sizable economics literature has documented the importance of high replacement costs for strike success (Cramton and Tracy 2003), and we undertake an empirical analysis in this spirit here. We begin by regressing a "successful strike" dummy variable ${ }^{18}$ on city and year fixed effects, as well as the log of employment at the firm in question. We then plot the residuals from this regression against the (residualized) fraction of replacement workers hired during the strike. One can see in the left panel of Figure 5 that there is a strong negative relationship between the success of a strike and the use

Bailey (1991) finds evidence that some strikes were not covered by the reports.

${ }^{17}$ See Cramton and Tracy (2003) for a more comprehensive review of the literature on labor disputes.

${ }^{18}$ Card and Olson (1995) note that in the last two decades of the 19 th century around $80 \%$ of strikes ended with a clear victory or defeat for the striking workers. 
of replacement workers. In the right panel of Figure 5, one can see that the hiring of replacement workers also translated into smaller wage gains resulting from a strike. ${ }^{19}$
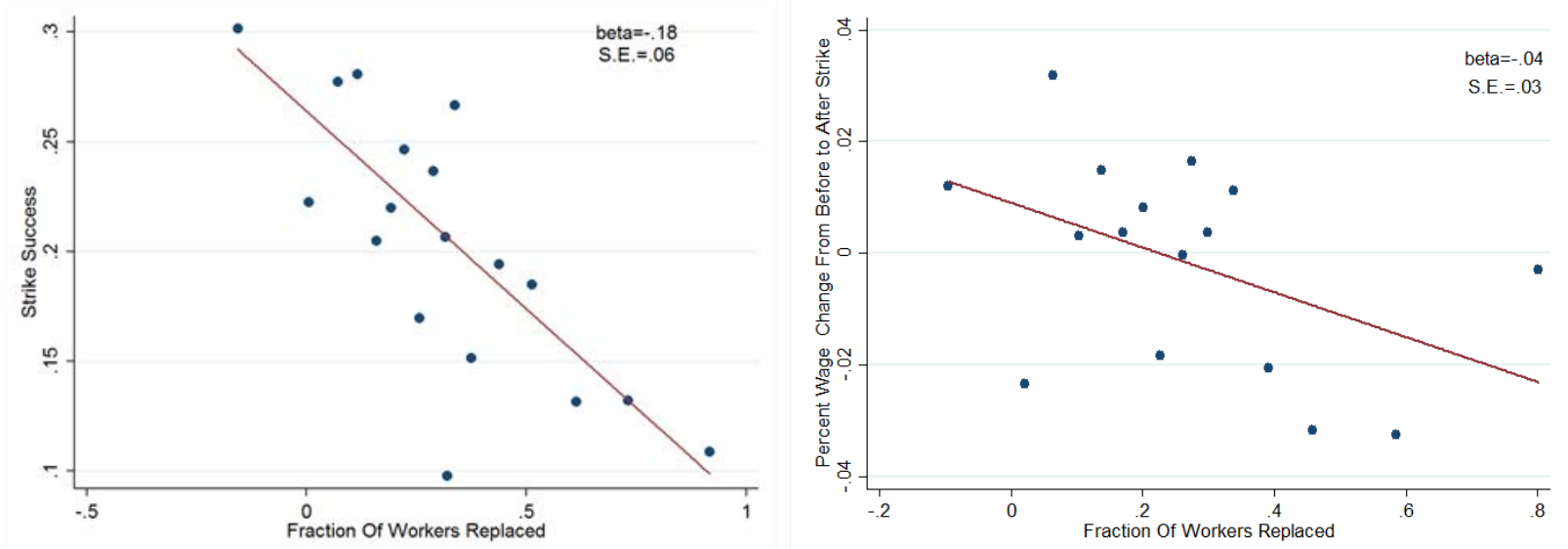

Figure 5: Replacement workers and strike outcomes, for strikes with a positive number of replacement workers. Left panel plots residualized strike success dummy variable against residualized fraction of replacement workers hired. Right panel plots residualized change in a firm's wage bill (post- minus pre-strike) against residualized fraction of replacement workers hired. Data come from the Third and Tenth Commissioner of Labor Reports.

Different from the regulated strike environment created under the New Deal, 19th century strikes were often borderline illegal. Striking workers, particularly the unskilled, naturally attempted to prevent the hiring of replacements, often using force. ${ }^{20}$ Many workers believed they had "property rights" in their jobs, making the use of force legitimate in their eyes. Organizing and paying for the coercive capacity to prevent employers from hiring replacement workers could be a massive undertaking. For example, Brecher (1972) describes the organization of the Amalgamated Association of Iron and Steel Workers during the Homestead strike near Pittsburgh in 1892:

In preparation for the strike, the Amalgamated had formed an Advisory Committee of five delegates from each of its eight lodges. Since the Amalgamated Association included only 750 of the 3,800 workers at Homestead, the Advisory Committee called on the rest to support the strike. Three thousand workers packed into the Homestead Opera House and voted overwhelmingly that everyone would strike - for the semiskilled and unskilled workers feared that their wages would be reduced as well. The Advisory Committee then circulated the following statement: "The Committee has, after mature deliberation, decided to organize their forces on a truly military basis. The force of four thousand men has been divided into three divisions or watches, each of these divisions

\footnotetext{
${ }^{19}$ Figure 5 includes only those strikes in which there was non-zero hiring of replacement workers. The negative relationship between replacement workers and strike success and wage gains is even more striking if strikes without any replacement hires are included.

${ }^{20}$ Fishback (1995) describes the use of force on both sides of labor conflicts as a prisoners' dilemma, in which each side was better off arming than not, yet both sides paid the price of the non-cooperative equilibrium.
} 
is to devote eight hours of the twenty-four to the task of watching the plant. The Commanders of these divisions are to have as assistants eight captains composed of one trusted man from each of the eight local lodges."

Employers responded to striking workers' use of coercion with force of their own. Sometimes this force was privately organized. Voss (1993) shows that employer associations played a crucial role in suppressing the Knights of Labor in New Jersey in the 19th century. New York City elites privately organized to limit labor violence (Beckert, 2001). ${ }^{21}$ Employers also hired the Pinkerton National Detective Agency ("the Pinkertons") to break strikes: Brecher (1972) notes that "[The Pinkertons'] 2,000 active agents and 30,000 reserves totaled more than the standing army of the nation." Pinkertons could infiltrate and sabotage unions, and could also be used in direct physical conflict with strikers, as in the Homestead strike.

More generally, state institutions - political and legal-determined how aggressively strikers could behave, and how forcefully employers could respond to workers' actions. Friedman (1988), analyzing France and United States in the 19th century, suggests that mass strikes were less effective in the U.S. than in France because employers were more likely to benefit from government intervention in America. ${ }^{22}$ Government intervention at its most dramatic took the form of the deployment of both the state militia and federal army regulars (Cooper, 1980). Riker (1957) presents data showing that between 1877 and 1892, the modal use of American militia was to quell labor unrest (33 of 112 instances, 8 times the the number of uses in response to natural disasters). In Figure 6, one can see that states' militia spending was also positively and significantly related to the number of striking workers. Government intervention also took the form of legal injunctions that legitimized the use of force by the state (if necessary). We next turn to the role of the judiciary in shaping the rules governing conflict in the labor market.

\footnotetext{
${ }^{21}$ Even university students volunteered as strike breakers and enlisted in militia, with Harvard and MIT students used to break the Lawrence Textile strike, Yale students volunteering as replacement workers for railroad workers and team drivers during strikes in 1903 and 1905, and University of Minnesota varsity athletes charging flour mill pickets in Minneapolis (Norwood 2002).

${ }^{22}$ Of course, political considerations alone did not determine the prevalence or intensity of strikes. Along with the economic incentives on which we focus here, social factors were certainly important as well. Biggs (2003) argues that there are powerful positive feedback loops, so strikes give rise to further strikes; Biggs (2005) uses a "forest-fire" model to explain the pattern of strikes.
} 


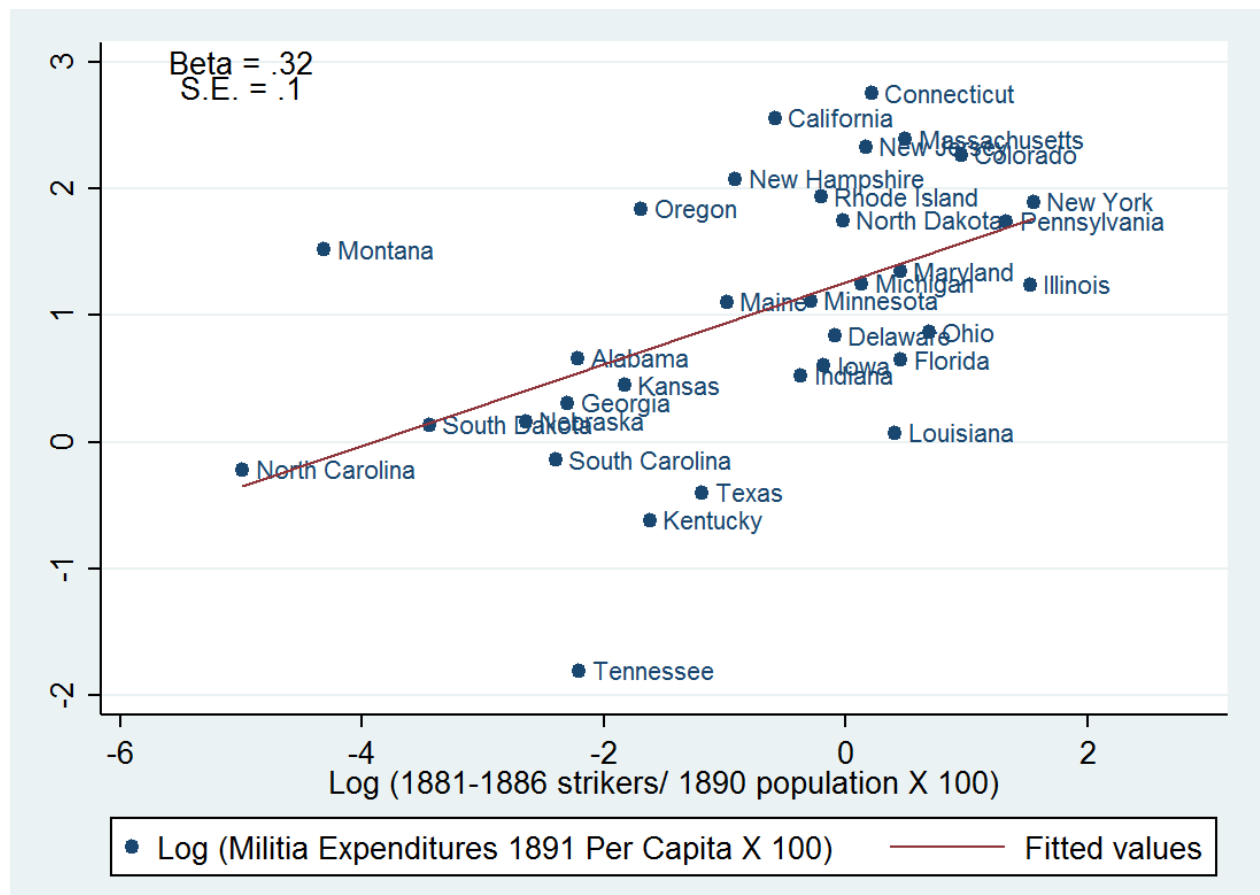

Figure 6: Militia spending and strikers. Figure plots the log of militia expenditures per capita against the number of striking workers per capita, by state. Data come from Riker (1957).

\section{Judicial Ideology and the Role of Courts}

While employers often received the support of sheriffs, governors, and even the President of the United States in labor conflicts, elected officials could not always be relied on. A labor movement with popular support and sympathy could threaten officials' re-election and thus win pro-labor policies. The historical strike record includes many instances of state sympathy for labor: local police forces or militias might refuse to fight with strikers and instead join them. Governors and legislators, too, sometimes found themselves reluctant to invoke force to break strikes, fearing political repercussions.

However, the most influential institution governing labor conflict in the late 19th century was not under electoral contest; it was the body of common law, as interpreted by the courts. ${ }^{23}$ The common law of employment, inherited from England, was heavily influenced by the doctrine of Master and Servant, which restricted the ability of most employees to leave their employers. ${ }^{24}$ In extreme cases - apprenticeship, indentured servitude, and especially slavery - these restrictions allowed colonial American employers to extract greater labor effort without paying market wages.

\footnotetext{
${ }^{23}$ We follow Orren (1991) in pointing to the fundamental role played by the courts in governing the American labor market in the 19th century. Note that while some American judges were subject to elections, they were more insulated from ballot pressure than other officials.

${ }^{24}$ See Tomlins (2004) on the use of Master and Servant law in 16th through 19th century America; Naidu and Yuchtman (2013) for an analysis of the use of Master and Servant law in 19th century Britain; and, Naidu (2010) on the use of anti-enticement laws in the postbellum U.S. South.
} 
Gradually, however, Republican ideology and economic forces eroded the individual coercion available under common law. Differing from Britain, American labor law stayed in the hands of courts in the late 19th century: indeed, Forbath (1991) points to the difference between "judicial supremacy" in the United States and "parliamentary supremacy" in Britain as crucial to the diverging labor movements in the two countries.

Horwitz (1977) describes the evolution of American law in the 19th century as the "triumph of contract". This overarching ideology enshrined in legal practice, together with the weight of common law, created a bench that was largely opposed to the legislative goals and the direct bargaining tactics of the labor movement. Thus, although American courts recognized unions as legal in Commonwealth v. Hunt ${ }^{25}$, this legality was based on the individual's freedom of contract. Because termination of employment was well within the liberal American tradition, striking alone was not illegal. However, the tactics that made strikes succeed in the late 19th century often involved persuasion and coercion - for example, attempts to prevent the hiring of potential replacement workers - and were viewed as illegal acts that restricted employers' and replacement workers' freedom of contract. ${ }^{26}$ Professional discipline, shaped by bar associations (the American Bar Association was founded in 1878) and respect for precedent, constrained even labor-sympathetic judges. The result was a vigorous defense of individuals' right to contract that severely limited the ability of legislation to intervene in the labor market. Orren (1991) shows that while $11 \%$ of all anti-business statutes were ever overturned by the judiciary, $75 \%$ of labor statutes were.

The institutional innovation that most effectively pacified labor violence was the labor injunction. At the behest of employers, judges issued injunctions ordering employees to return to work and allowing government forces to break up pickets and other activities that prevented replacements from working. In laying the groundwork for the injunction, the judiciary confronted legal dilemmas that were fundamental to the American constitution, pitting rights to property and contract against rights to freedom of association and speech. For example, three powerful tactics for strikers were picketing, the sympathy strike and the secondary boycott. Judges issued injunctions against all of these tactics, arguing that picketing violated employer property rights, that sympathy strikes constituted enticement, and that secondary boycotts violated the Sherman Act.

Witte (1931) describes a series of (failed) attempts to pass federal legislation to limit judicial injunctions as follows:

For more than a generation organized labor has sought relief through legislation from "government by injunctions." From 1895, when the first anti-injunction bill was introduced, to 1914, this was an important question in every Congress. Three times - in 1897, 1902, and 1912 - anti-injunction bills passed one house only to fail in the other. President Roosevelt recommended action to curb the "abuse" of injunctions in no less

\footnotetext{
${ }^{25}$ The case is 45 Mass. 111 (1842).

${ }^{26}$ Workers did not accept this interpretation of the constitution or the underlying "free labor" ideology. Unions had their own shadow jurisprudence and vision of what the constitution allowed. For example, some unions interpreted the 13th Amendment as guaranteeing the right to strike. Interestingly, Gourevitch (2014) shows that the underlying Republican labor ideology also articulated many of the labor market imperfections that economists would recognize.
} 
than five of his messages to Congress. Because Republican Congresses refused to pass such a law, the American Federation of Labor launched its nonpartisan political policy and in 1908 and 1912 endorsed the Democratic candidates for president. Finally, when the Democrats gained control of all branches of the government, the Clayton Act was enacted and labor heralded the labor sections of this measure as a combined magna charta and bill of rights. Within a few years, these sections were construed by the Supreme Court to have made no change in the law except to confer the right of trial by jury in a restricted class of contempt cases.

To document the rising use of the injunction as a response to labor disputes, we identify all labor injunction cases in Westlaw and LexisNexis for the time period 1877-1930. Specifically, we searched for "injunction" and (labor OR strike OR workers OR collective bargaining OR combination). ${ }^{27}$ Note that many (in fact, most) local court cases that were not appealed are not catalogued in either LexisNexis or Westlaw, so we observe only the tip of the iceberg: still, we find 586 such cases, excluding duplicates (in the sense of reaching multiple court levels). ${ }^{28}$

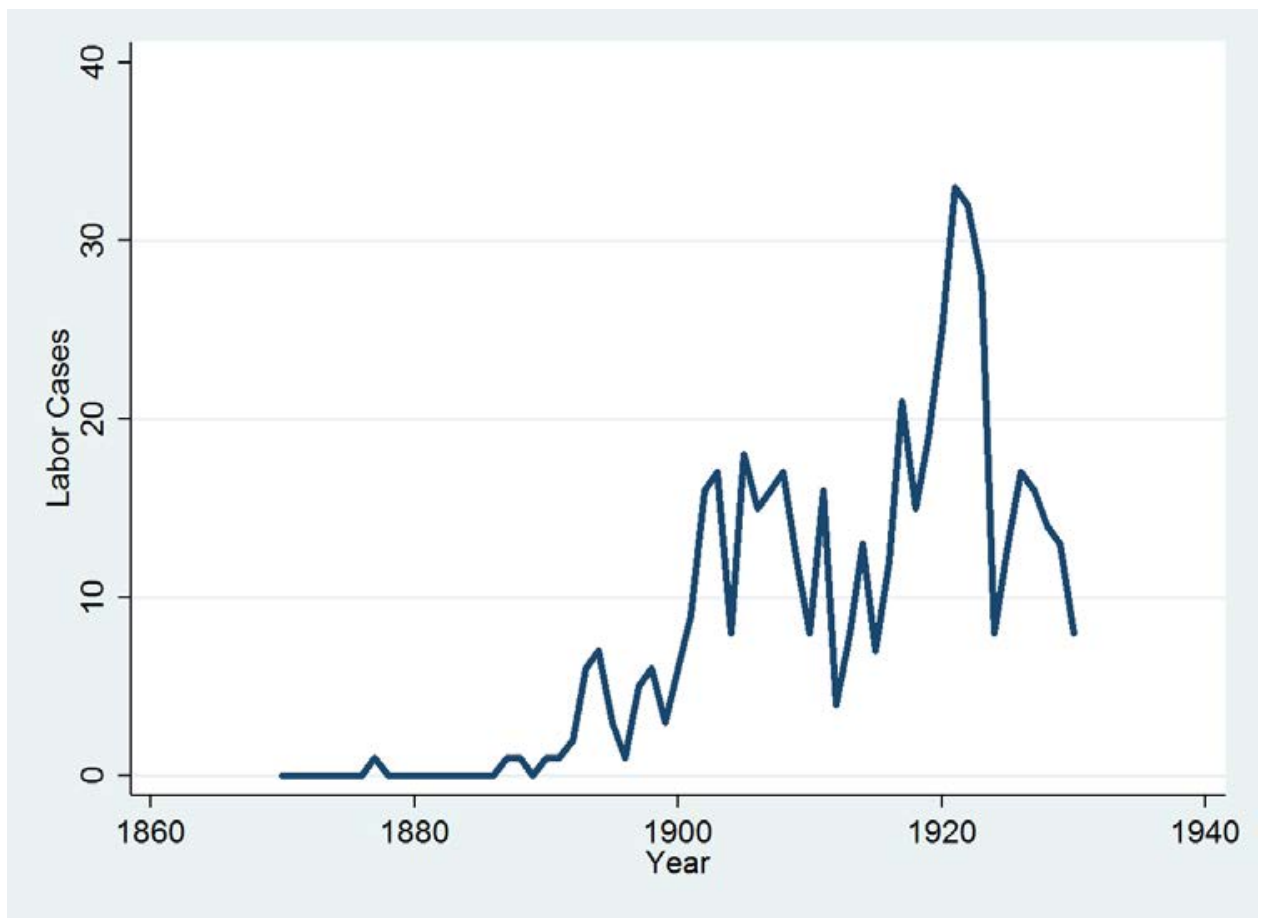

Figure 7: Figure shows counts from Lexis-Nexis and Westlaw, based on a search for "injunction" and (labor OR strike OR workers OR collective bargaining OR combination), and reading of cases to ensure that injunctions were issued in response to labor disputes.

In Figure 7, we plot the time series of injunctions across time. One can see a steady increase

\footnotetext{
${ }^{27}$ Cases were read to ensure that injunctions issued were in response to labor disputes.

${ }^{28}$ Note also that observed injunctions are an imperfect indicator of injunctions' impact on bargaining over rents, as they may have been important as a threat off the equilibrium path.
} 
from the mid-1880s, with a sharp spike in the early 20th century and a high level throughout the period prior to the New Deal. Comparing Figures 4 and 7, one can see that the late 19th and early 20th centuries were a period with both the highest levels of violent labor conflict and also the period with the greatest number of injunctions. ${ }^{29}$

Labor conflict continued, despite the limits imposed on strikes, in part because the contract law did not recognize a right for workers to be represented by unions. The labor movement expanded during World War I when the federal government shifted attitudes and began to support collective bargaining in its contracts. The war's end and the federal government's decreased involvement in the economy touched off a series of conflicts over the recognition of unions that led to a decline in unionization during the 1920s. As part of the New Deal, the federal government recognized a right to unionize when more than 50 percent of workers from the same employer voted for unionization under the National Labor Relations Act, which was upheld by the Jones 85 Laughlin Supreme Court decision in 1937. ${ }^{30}$ The NLRA also moved labor law into the domain of administrative law created by the National Labor Relations Board. The result was an increase in union membership that carried through the war. The more than 100 million man-days lost to strikes in 1946 and the postwar weakening of the New Deal Democrat coalition ${ }^{31}$ led to the passage of the Taft-Hartley Act in 1947, which put more restrictions on strikes and collective bargaining (Katznelson, 2013). The share of private-sector workers in unions peaked in the 1950s and has generally declined since that time.

\section{Concluding Thoughts and Directions for Future Research}

In this chapter we document characteristics of late 19th century labor markets in the Northern U.S., pointing to the important role played by labor market institutions in determining wages and the distribution of income, even in a context of limited formal regulation. First, we provide evidence of substantial frictions, which generated rents even in urban labor markets. This created a space for bargaining and conflict between workers and firms. Indeed, the second fact we document is the presence of substantial labor market conflict. We further show that strikes were associated with higher wages and that a major determinant of a successful strike was the ability to restrict the use of replacement workers. Thus, physical coercion by workers (preventing the hiring of their replacements) was a critical aspect of strikes - one which invited a forceful response by employers, and the state acting on employers' behalf. Finally, we show that the judicial system played an important role in legitimizing the use of state coercion to end strikes in the 19th and early 20th

\footnotetext{
${ }^{29}$ This might be puzzling at first: one might expect that when the technology of repressing strikes improves the most violent strikes and most costly conflict would decline. However, in contest models with asymmetric payoffs (for example, Nti, 1999), the effect of extra repression on wasteful effort is ambiguous. A fall in unions' valuation of winning a strike (due to greater repression) may actually increase employer mobilization. This (or simply other variables) may explain why the highest levels of conflict occur at the same time as greater number of legal injunctions.

${ }^{30}$ The case is National Labor Relations Board v. Jones 8 Laughlin Steel Corporation, 301 U.S. 1 (1937). More detail is available in the chapter on the New Deal by Price Fishback.

${ }^{31}$ The CIO's "Operation Dixie" to organize Southern labor was launched in 1946, generating hostility from Southern Democrats.
} 
centuries.

By focusing here on conflict over rents in the labor market, we do not wish to diminish the importance of many other features of the 19th century labor market. ${ }^{32}$ We chose to focus on conflict both because it has been relatively neglected in economists' research on labor markets (relative to the attention received from other social scientists), and because we believe that there exist exciting paths forward for synthesizing the recent literature on the political economy of conflict with economic history research on labor markets.

For example, at a macroeconomic level, the role of conflict in building state capacity has long been observed by scholars (e.g., Besley and Persson, 2009). It is interesting to note that military and law enforcement institutions of the United States, in particular the Army, the National Guard, and the FBI, can trace their origins to the federal troops, state militias, and private Pinkertons deployed in 19th century labor conflicts (see, e.g., Skowronek, 1982; Laurie and Cole, 1997; and, Morn, 1982).

At a microeconomic level, currently, no comprehensive, disaggregated, dataset on strikes exists, but we believe that exploiting natural language processing techniques, it is only a matter of time (and some effort) to put together far more complete data than are currently available. With vast swaths of 19th century newspapers digitized (reporting on strikes and labor unrest more generally) and the 3rd and 10th Commissioner of Labor reports as training data, text classification methods and hand-coding could conceivably be deployed to fill in the gaps in the Commissioner of Labor report data. Such methods could also be used to construct a dataset measuring a variety of additional outcomes of interest. For example, newspaper descriptions of strikes often mentioned violations of civil rights, violence, or deaths. ${ }^{33}$ Rich, disaggregated strike data could, among other things, be linked to available asset price data for the 19th century to examine the impact of strikes on listed firms' values. ${ }^{34}$

Finally, little of the literature estimating the effects of strikes (or labor market institutions), has exploited exogenous variation in strikes' incidence. Given the numerous sources of political variation (e.g., electoral regression discontinuities), weather variation (rainfall, heat, etc.), and sharp policy changes (either judicial or legislative), there seems to be ample scope for hypothesis testing regarding strikes' causes, and for empirical analyses of strikes' causal effects.

We close with some thoughts on the relevance of the past to our understanding of the present. Inequality has risen in recent decades to levels last seen in the early 20th century. While very different from the violent strikes of 125 years ago, contemporary labor movements continue to wield de facto political power to try to increase their share of the pie. Recent worker mobilizations

\footnotetext{
${ }^{32}$ As noted above, changes in the levels of human capital, technological change, and the rise of mass-migration dramatically affected the American labor market in the late 19th century (see, for example, Abramitzky et al., 2012, and Goldin and Katz, 2008). Race also played a crucial role in determining labor market outcomes (see Hornbeck and Naidu, 2014).

${ }^{33}$ Automated and computer-assisted coding methods have been used to produce useful datasets on violence in contemporary data-poor environments, such as India (Fetzer, 2014).

${ }^{34}$ Baker et al. (2014) use the asset price data to examine the effect of (pro-business) McKinley's assassination by an anarchist labor radical, and the accession to power of (reformer) Teddy Roosevelt, on stock prices of firms vulnerable to antitrust prosecution. DiNardo and Hallock (2002) link strikes to firm values in the early 20th century.
} 
in the United States have won local minimum wage mandates, and pressured firms to raise wages independently of legislation. Paralleling the restrictive role of 19th century law and courts are binding arbitration clauses in union contracts, continued judicial injunctions, and NLRB restrictions on unionization drives, which have restricted the tactics available to unions and would-be unions. Inequality and conflict over the distribution of wealth and income thus remain relevant more than a century after the Gilded Age. A better understanding of the causes and consequences of conflicts in the past may reduce the costs of such conflicts in the future. 


\section{References}

Abramitzky, Ran, Leah Platt Boustan, and Katherine Eriksson (2012). "Europe's Tired, Poor, Huddled Masses: Self-Selection and Economic Outcomes in the Age of Mass Migration," American Economic Review, 102(5), pp. 1832-1856.

Atack, Jeremy, Fred Bateman, and Robert A. Margo (2002). "Part Year Operation in Nineteenth Century Manufacturing: Evidence from the 1870 and 1880 Censuses," Journal of Economic History, 62(3), pp. 792-809.

Atack, Jeremy, Fred Bateman, and Robert A. Margo (2003). "Productivity in Manufacturing and the Length of the Working Day: Evidence from the 1880 Census of Manufactures," Explorations in Economic History, 40, 170-194.

Atack, Jeremy, Fred Bateman, and Robert A. Margo (2004). "Skill Intensity and Rising Wage Dispersion in Nineteenth Century American Manufacturing," Journal of Economic History, 64(1), pp. 172-192.

Atack, Jeremy, Fred Bateman, and Robert A. Margo (2008). "Steam Power, Establishment Size, and Labor Productivity Growth in Nineteenth Century American Manufacturing," Explorations in Economic History, 45, pp. 185-198.

Bailey, Gary L. (1991). "The Commissioner of Labor's Strikes and Lockouts: A Cautionary Note," Labor History, 32, pp. 432-440.

Baker, Richard B., Carola Frydman, and Eric Hilt (2014). "From Plutocracy to Progressivism? The Assassination of President McKinley as a Turning Point in American History," Boston University working paper.

Beckert, Sven (2001). The Monied Metropolis. Cambridge, UK: Cambridge University Press.

Besley, Timothy and Torsten Persson. (2009). "The Origins of State Capacity: Property Rights, Taxation, and Politics," American Economic Review, 99(4), pp. 1218-1244.

Biggs, Michael. (2003). "Positive Feedback in Collective Mobilization: The American Strike Wave of 1886," Theory and Society, 32, pp. 217-54.

Biggs, Michael (2005). "Strikes as Forest Fires: Chicago and Paris in the Late Nineteenth Century," American Journal of Sociology, 110(6), pp. 1684-1714. 
Boal, William M. (1995). "Testing for Employer Monopsony in Turn-of-the-Century Coal Mining," Rand Journal of Economics, 26(3), pp. 519-36.

Bowles, Samuel and Arjun Jayadev (2006). "Guard Labor," Journal of Development Economics, $79(2)$, pp. 328-348.

Brecher, Jeremy (1972). Strike! San Francisco: Straight Arrow Books.

Brody, David (1960). Steelworkers in America: The Nonunion Era. Cambridge, MA: Harvard University Press.

Card, David, Ana Rute Cardoso, Jörg Heining, and Patrick Kline (2016). "Firms and Labor Market Inequality: Evidence and Some Theory," UC-Berkeley working paper.

Card, David and Craig Olson (1995). "Bargaining Power, Strike Durations, and Wage Outcomes: An Analysis of Strikes in the 1880s," Journal of Labor Economics, 13(1), pp. 32-61.

Carter, Susan B. and Elizabeth Savoca (1990). "Labor Mobility and Lengthy Jobs in Nineteenth-Century America," Journal of Economic History, 50(1), pp. 1-16.

Chandler, Jr., Alfred D. (1977). The Visible Hand: The Managerial Revolution in American Business. Cambridge, MA: Harvard University Press.

Cramton, Peter and Joseph Tracy (2003). "Unions, Bargaining and Strikes," Chapter 4 in John T. Addison and Claus Schnabel eds., International Handbook of Trade Unions. Cheltenham, UK: Edward Elgar.

Commons, John R. (1918). History of Labour in the United States. New York, NY: Macmillan.

Cooper, Jerry (1980). The Army and Civil Disorder: Federal Military Intervention in Labor Disputes, 1877-1900. Westport, CT: Greenwood Press.

Currie, Janet and Joseph Ferrie (2000). "The Law and Labor Strife in the U.S., 1881-1894," Journal of Economic History, 60(1), pp. 42-66.

Davis, Steve J. and John Haltiwanger (1991). "Wage Dispersion Between and Within US Manufacturing Plants, 1963-86," Brookings Papers on Economic Activity: Microeconomics, pp. 115-200. 
Dinardo, John and Kevin F. Hallock (2002). "When Unions 'Mattered': The Impact of Strikes on Financial Markets, 1925-1937," Industrial and Labor Relations Review, 55(2), pp. 219-233.

Douglas, Paul H. (1930). Real wages in the United States, 1890-1926. Boston, MA: Houghton Mifflin Co.

Eichengreen, Barry J. (1987). "The Impact of Late Nineteenth Century Unions on Labor Earnings and Hours: Iowa in 1894," Industrial and Labor Relations Review, 40, pp. 501-15.

Esteban, Joan and Debraj Ray (2011). "Linking Conflict to Inequality and Polarization" American Economic Review, 101(4), pp. 1345-1374.

Fetzer, Thiemo (2014). "Social Insurance and Conflict: Evidence from India," Warwick University working paper.

Fishback, Price V. (1992). "The Economics of Company Housing: Theoretical and Historical Perspectives from the Coal Fields," Journal of Law, Economics, and Organization, 8, pp. 346-365.

Fishback, Price V. (1995). "An Alternative View of Violence in Strikes: The Bituminous Coal Industry, 1890-1930," Labor History, 36, pp. 426-456.

Fishback, Price V. (1998). "Operations of 'Unfettered' Labor Markets: Exit and Voice in American Labor Markets at the Turn of the Century," Journal of Economic Literature, 36, pp. 722-765.

Friedman, Gerald (1988). "Strike Success and Union Ideology: The United States and France, 1880-1914," Journal of Economic History, 48(1), pp. 1-25.

Forbath, William E. (1991). "Courts, Constitutions, and Labor Politics in England and America: A Study of the Constitutive Power of Law," Law $\&$ Social Inquiry, 16(1), pp. 1-34.

Gilje, Paul A. (1996). Rioting in America. Bloomington, IN: Indiana University Press.

Goldin, Claudia (2000). "Labor Markets in the Twentieth Century," in Stanley L. Engerman, and Robert E. Gallman eds., The Cambridge Economic History of the United States, vol. III., pp. 549-624. Cambridge, UK: Cambridge University Press.

Goldin, Claudia and Lawrence F. Katz (1998). "The Origins of Technology-Skill Complementarity." Quarterly Journal of Economics, 113, pp. 693-732. 
Goldin, Claudia and Lawrence F. Katz (2008). The Race Between Education and Technology. Cambridge, MA: The Belknap Press of Harvard University Press.

Gourevitch, Alexander (2015). From Slavery to the Cooperative Commonwealth: Labor and Republican Liberty in the Nineteenth Century. New York, NY: Cambridge University Press.

Hanes, Christopher (1993). "The Development of Nominal Wage Rigidity in the Late 19th Century," American Economic Review, 83(4), pp. 732-756.

Hatton, Timothy J., George R. Boyer, and Roy E. Bailey (1994). "The Union Wage Effect in Late Nineteenth Century Britain," Economica, 61(4), pp. 435-456.

Historical Statistics of the United States, 2006. Edited by Susan B. Carter, Scott Sigmund Gartner, Michael R. Haines, Alan L. Olmstead, Richard Sutch, and Gavin Wright. Cambridge, UK: Cambridge University Press.

Hornbeck, Richard and Suresh Naidu (2014). "When the Levee Breaks: Black Migration and Economic Development in the American South," American Economic Review, 104(3), pp. 963-90.

Horwitz, Morton J. (1977). The Transformation of American Law, 1780-1860. Cambridge, MA: Harvard University Press.

Jacoby, Sanford and Sunil Sharma (1992). "Employment Duration and Industrial Labor Mobility in the United States 1880-1980," Journal of Economic History, 52(1), pp. 161-179.

Jäger, Simon (2015). "How Substitutable are Workers? Evidence from Worker Deaths," Harvard University working paper.

Katz, Lawrence F. and Robert A. Margo (2014). "Technical Change and the Relative Demand for Skilled Labor: The United States in Historical Perspective," in Leah Platt Boustan, Carola Frydman, and Robert A. Margo eds., Human Capital in History, pp. 15-58. Chicago, IL: University of Chicago Press.

Katz, Lawrence F. and Lawrence H. Summers (1989). "Industry Rents: Evidence and Implications," Brookings Papers on Economic Activity, Microeconomics, pp. 209-290.

Katznelson, Ira (2013). Fear Itself. New York, NY: Norton Publishing.

Laurie, Clayton D. and Ronald H. Cole (1997). The Role of Federal Military Forces in Do- 
mestic Disorders, 1877-1945. Washington, DC: Center of Military History, U.S. Army.

Levy, Sheldon G. (1991). Political violence in the United States, 1819-1968. Ann Arbor, MI: Inter-University Consortium for Political and Social Research.

Montgomery, David (1987). The Fall of the House of Labor: The Workplace, the State, and American Labor Activism, 1865-1925. Cambridge, UK: Cambridge University Press.

Morn, Frank (1982). "The Eye That Never Sleeps": A History of the Pinkerton National Detective Agency. Bloomington, IN: Indiana University Press.

Naidu, Suresh (2010). "Recruitment Restrictions and Labor Market Outcomes, Evidence from the Post-Bellum South," Journal of Labor Economics, 28(2), pp. 413-445.

Naidu, Suresh, and Noam Yuchtman (2013). "Coercive Contract Enforcement: Law and the Labor Market in Nineteenth Century Industrial Britain," American Economic Review, 103(1), pp. 107-44.

Norwood, Stephen H. (2002). Strikebreaking \& Intimidation: Mercenaries and Masculinity in Twentieth-century America. Chapel Hill: University of North Carolina Press.

Nti, Kofi O. (1999). "Rent-Seeking with Asymmetric Valuations," Public Choice, 98(3/4), pp. 415430.

Orren, Karen (1991). Belated Feudalism: Labor, the Law, and Liberal Development in the United States. Cambridge, UK: Cambridge University Press.

Piketty, Thomas (2014). Capital in the Twenty-first Century. Cambridge, MA: The Belknap Press of Harvard University Press.

Piketty, Thomas and Gabriel Zucman (2014). "Capital is Back: Wealth-Income Ratios in Rich Countries, 1700-2010." Quarterly Journal of Economics, 129(3), pp. 1255-1310.

Riker, William H. (1957). Soldiers of the States; The Role of the National Guard in American Democracy. Washington, DC: Public Affairs Press.

Roine, Jesper and Daniel Waldenström (2015). "Long run trends in the distribution of income and wealth," in A.B. Atkinson \& F. Bourguignon eds., Handbook in Income Distribution, vol. 2. Amsterdam: North-Holland. 
Rosenbloom, Joshua L. (1996). "Was There a National Labor Market at the End of the Nineteenth Century? New Evidence on Earnings in Manufacturing," Journal of Economic History, 56, pp. 626-656.

Rosenbloom, Joshua L. (1998). "Strikebreaking and the Labor Market in the United States, 1881-1894," Journal of Economic History, 58, pp. 183-205.

Saez, Emmanuel and Gabriel Zucman (2016). "Wealth Inequality in the United States since 1913: Evidence from Capitalized Income Tax Data," Quarterly Journal of Economics, 131(1).

Skowronek, Stephen (1982). Building a New American State: The Expansion of National Administrative Capacities, 1877-1920. Cambridge, UK: Cambridge University Press.

Sundstrom, William A. (1988). "Internal Labor Markets before World War I: On-the-Job Training and Employee Promotion," Explorations in Economic History, 25(4), pp. 424-445.

Tomlins, Christopher (2004). "Early British America, 1585-1875: Freedom Bound." in Douglas Hay and Paul Craven eds., Masters, Servants and Magistrates in Britain and the Empire 15621955. Chapel Hill, NC, University of North Carolina Press.

Turchin, Peter (2012). "Dynamics of Political Instability in the United States, 1780-2010." Journal of Peace Research, 49(4), pp. 577-591.

U.S. Commissioner of Labor (1888). Third Annual Report. Washington, DC: Government Printing Office.

U.S. Commissioner of Labor (1896). Tenth Annual Report. Washington, DC: Government Printing Office.

Vedder, Richard K, Lowell E. Gallaway, and David Klingaman (1978). "Discrimination and Exploitation in Antebellum American Cotton Textile Manufacturing," Research in Economic History, 3, pp. 217-262.

Voss, Kim (1993). The Making of American Exceptionalism: The Knights of Labor and Class Formation in the Nineteenth Century. Ithaca, NY: Cornell University Press.

Weeks, Joseph D. (1886). Report on the Statistics of Wages in Manufacturing Industries with Supplementary Reports. Washington, DC: Government Printing Office. 
Witte, Edwin E. (1931). "The Federal Anti-Injunction Act,” Minnesota Law Review, 16, p. 638.

Zevin, Robert B. (1975). The Growth of Manufacturing in Early Nineteenth Century New England. New York, NY: Arno Press, 1975.

Ziebarth, Nicolas L. (2013). "Are China and India backward? Evidence from the 19th century U.S. Census of Manufactures," Review of Economic Dynamics, 16: pp. 86-99. 